\title{
Volatile Organic Compounds Inside Urban Tunnels of São Paulo City, Brazil
}

\author{
Pérola C. Vasconcellos*, Lilian R. F. Carvalho and Cristina S. Pool \\ Instituto de Química, Universidade de São Paulo, CP 26077, 05599-970 São Paulo- SP, Brazil
}

Compostos orgânicos voláteis, tais como hidrocarbonetos oxigenados, hidrocarbonetos alifáticos e aromáticos foram medidos no ar interno de dois túneis urbanos da cidade de São Paulo, Brasil. Nesses túneis são freqüentes os congestionamentos de tráfico com números expressivos de veículos com controle de emissão inadequada. São Paulo, uma cidade altamente poluída, apresenta uma frota atípica de veículos com uma variedade grande de misturas de combustíveis, incluindo os oxigenados. Nesse trabalho, foram feitas medidas no ar interno e externo do túnel para avaliar os níveis dos poluentes emitidos diretamente por veículos e aqueles formados fotoquimicamente na atmosfera. No túnel (A), onde circulam apenas veículos leves movidos principalmente por gasool, uma mistura contendo 78-80\% (v/v) gasolina e 20-25\% etanol, as razões de formaldeído/acetaldeído foram < 1; e no túnel (B), onde circulam veículos leves principalmente movidos a gasool e veículos pesados movidos a diesel, essas razões foram aproximadamente igual a 1. Em ambos os túneis, as razões ácido fórmico/ácido acético foram bem mais baixas do que 1. O benzaldeído foi sugerido como sendo um possível traçador de emissões de veículos leves movidos a gasool. Os $n$-alcanos foram os compostos mais abundantes (níveis semelhantes em ambos os túneis) e, em seguida os compostos carbonílicos (níveis mais altos em B) e os compostos aromáticos (níveis mais altos em A). Foram encontrados níveis semelhantes de ácidos orgânicos, espécies minoritárias, em ambos os túneis. Os resultados desse estudo mostram que poluentes tóxicos estão presentes em níveis significativos nos dois túneis. No túnel (A) foram encontrados razões de mistura de 39,2 e 24,8 ppbv para os agentes carcinogênicos formaldeído e benzeno; no túnel (B) um valor máximo de 34,5 ppbv foi encontrado para o acetaldeído, um provável agente carcinogênico. Estudos futuros devem ser feitos para estimar os níveis de exposição de poluentes tóxicos no ar para ocupantes de veículos, uma vez que essas pessoas passam um tempo significativo dentro de túneis urbanos.

Volatile organic compounds, such as oxygenated hydrocarbons, aliphatic and aromatic hydrocarbons were measured in ambient air from two distinct urban tunnels in São Paulo City, Brazil, in special, at rush hours. In these tunnels, traffic jams with significant numbers of vehicles with inadequate emission controls are frequent. São Paulo, a highly polluted city, has an unconventional mix of vehicle types in that a variety of gasoline blends, including oxygenated ones are used. Inside and outside tunnel measurements were performed to evaluate pollutant levels originated from direct vehicular emissions and formed by atmospheric photochemistry. Formaldehyde/acetaldehyde ratios of tunnel (A) circulating only light-duty vehicles fueled mainly with gasohol, a mixture containing $78-80 \%(\mathrm{v} / \mathrm{v})$ gasoline and $20-25 \%$ ethanol, were $<1$; ratios of tunnel (B) circulating light-duty vehicles fueled mainly with gasohol and heavy diesel vehicles, were approximately equal to 1 . Formic acid/acetic acid ratios of both tunnels were much lower than 1. Benzaldehyde was suggested as a possible tracer of light-duty gasohol vehicular emissions. $N$-alkanes were the most abundant compound class (similar levels in both tunnels) followed by carbonyl compounds (higher levels in B), and aromatics compounds (higher levels in A). Organic acids, the minor species, were found at similar levels in both tunnels. Results of this survey show that toxic pollutants are present at significant levels in both tunnels. Formaldehyde and benzene, human carcinogenic agents, presented maximum mixing ratios of 39.2 and 24.8 ppbv, respectively, inside tunnel A; acetaldehyde, a probable human carcinogenic, reached a maximum of $34.5 \mathrm{ppbv}$ inside tunnel B. Since vehicle occupants that spend a significant time in urban tunnels are commonly exposed to toxic pollutant emissions, future extensive studies should be done in order to estimate exposure levels of toxic ambient air pollutants for these people.

Keywords: Volatile organic compounds, tunnel measurements, brazilian vehicular fleet

* e-mail: perola@iq.usp.br 


\section{Introduction}

Air pollution is widespread in megacities and it is often most severe in developing countries. Road traffic is one of the most significant sources of primary air pollutants in the industrialized world. In urban areas, nitrogen oxides, volatile organic compounds (VOCs) and $\mathrm{CO}$ are the precursors for photo-oxidant formation in ambient air. VOCs are of great concern in urban air pollution and as precursors for ozone formation because of their abundance in motor vehicle emissions and their high ozone formation potential. ${ }^{1}$ The main VOC sources in urban atmosphere are combustion emissions that arise predominantly from vehicular motor exhaust. Because VOCs have very different chemical reactivities, the speciation of VOCs emitted from motor vehicles is very important for estimating their effect on ozone budget. ${ }^{1}$ VOCs are of great concern not only because it is an ozone precursor, but also because some of them are carcinogenic chemicals. Toxic pollutants from vehicle emissions may accumulate in tunnels and be hazardous to human exposure. ${ }^{2}$ Tunnel studies have been used to evaluate the chemical composition of the vehicular motor exhaust emissions, as photochemical reactions do not occur inside tunnel and direct emissions from vehicles may be measured. In general, the measured concentrations of pollutants emitted from motor vehicular exhaust in tunnels are significantly higher than those found in ambient air.

The greater metropolitan area of the city of São Paulo (MASP) is the largest industrialized section of Latin America. The air quality of the MASP is affected by a complex system of mobile and stationary sources mixing in a topographically diverse area. São Paulo City is a megacity with serious air pollution problems. Diesel, neat ethanol and gasohol (a mixture of gasoline with anhydrous ethanol) are used as automotive fuels. In MASP, there are $\sim 6.5$ million automotive vehicles: 390000 heavy-duty (HD) diesels and 5.5 million lightduty (LD) vehicles. Approximately 4.2 million of the light duty cars are fueled with a gasohol and 1.1 million are fueled with hydrated ethanol. ${ }^{3}$ The ratio between the number of ethanol and gasoline cars has changed substantially in the past few years. In 1995, for instance, $97 \%$ of the cars produced in Brazil were fueled with gasohol, revealing a substantial reduction in the production of cars fueled with neat ethanol, which had reached $76 \%$ of national LD vehicle production in 1986. In 1989, nearly half of the LD cars were gasohol-fueled and the other half ethanol-fueled. From 1996 to 2000, there was a notable increase in the number of cars fueled with gasohol (25\%), whereas the number of cars fueled with neat ethanol remained at the previous level. ${ }^{3}$

Mixing ratios of volatile hydrocarbons emitted from vehicles inside tunnels of several cities have been reported worldwide. ${ }^{2,4-7}$ In some urban centers of Brazil, there have been reports on tunnel measurements of polycyclic aromatic hydrocarbons (PAHs) in airborne particles, ${ }^{8-10}$ gaseous aldehydes, ${ }^{11-13}$ gaseous carboxylic acids ${ }^{14}$ and VOCs. ${ }^{15}$

In order to evaluate chemical composition of emissions from vehicles fueled with gasoline blends with ethanol, neat ethanol and diesel, measurements of several VOCs were done in two different urban road tunnels located in São Paulo City, Brazil. In one of the tunnels circulates only LD vehicles fueled with gasohol and ethanol and in the other tunnel circulates HD vehicles fueled with diesel and LD vehicles. Results from tunnel measurements of VOCs, such as carbonyl compounds and carboxylic acids, as well as aliphatic and aromatic hydrocarbons are reported in this paper. Organics such as PAHs, which are mostly associated with airborne particles, are not discussed here but they are presented in our recent article in which characteristics PAH profiles from vehicular emissions of the fuels used in São Paulo are presented. ${ }^{10}$

\section{Experimental}

\section{Sampling sites characteristics}

Sampling of volatile organic compounds was performed in the two roadway tunnels air located in São Paulo City (Figure 1). Different types of vehicles circulate in the tunnels chosen. Only light duty (LD) vehicles are allowed to pass in the Jânio Quadros Tunnel (JQT) while both heavy-duty (HD) and LD vehicles move in the Maria Maluf Tunnel (MMT).

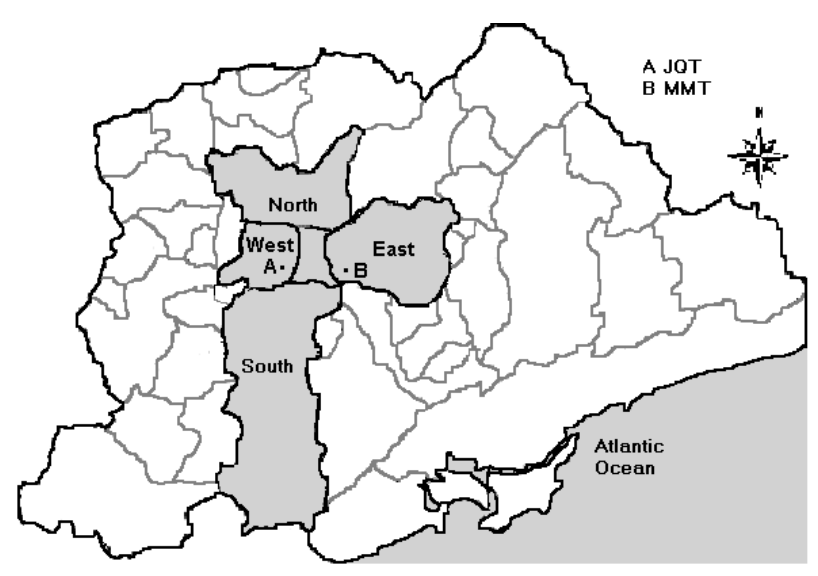

Figure 1. Map of the metropolitan area of São Paulo City showing local of the tunnels studied. 
The JQT has bi-direction two-lane carriageway with $1200 \mathrm{~m}$ length and $4 \mathrm{~m}$ height. A traffic volume of approximately 58000 vehicles is estimated daily. To ensure a good air quality inside this tunnel, three fans ventilation system $(2 \mathrm{~m}$ di $x 5 \mathrm{~m})$ is automatically turned on when CO levels are increased. The sampling local inside the tunnel was distant approximately $200 \mathrm{~m}$ from entrance.

The MMT has bi-direction three lanes with $845 \mathrm{~m}$ long and $5.6 \mathrm{~m}$ height. A concrete wall separates the tunnel into two directions and each direction has three lanes. A traffic volume of approximately 70000 vehicles is estimated daily. The sampling was performed in a pathway between two ways where air exchange between them certainly occurred. In this tunnel, the longitudinal ventilation caused by the piston effect of the traffic in the two directions is present.

In the JQT, emissions are from gasohol and ethanol fueled vehicles, and in the MMT, gasohol, ethanol and diesel fueled vehicles. Since the number of ethanol-fueled vehicles has decreased drastically in the last past years compared to gasohol-fueled vehicles in the MASP, ${ }^{10}$ we assume that light-duty vehicles inside the tunnels are mostly fueled by gasohol. Differences in the proportion of vehicle types in the MMT and density of vehicles in the JQT were observed at each sampling time period studied (Table 1). In the MMT, there was an increase of HD vehicles at the second sampling time, while the LD vehicles traffic was practically constant during the whole sampling time. On the other hand, the LD vehicle density in the JQT was gradually increased at each sampling time from morning to midday and midday to afternoon. Traffic volume through tunnels was manually counted.

Table 1. Sampling time period and traffic volume in both tunnels studied

\begin{tabular}{lc}
\hline Tunnel/Sampling time & Traffic volume \\
\hline MMT/8-10 am & $6931 \mathrm{LD}+928$ \\
HDMMT/10-12 am & $6746 \mathrm{LD}+1091$ \\
HDJQT/10-12 pm & $4781 \mathrm{LD}$ \\
JQT/12 am-2 pm & $5630 \mathrm{LD}$ \\
JQT/02-04 pm & $6113 \mathrm{LD}$ \\
\hline
\end{tabular}

LD = light-duty vehicles; $\mathrm{HD}$ = heavy-duty vehicles.

Tunnel sampling was performed on weekdays from 10 a.m. to 4 p.m. in the JQT (August, 2001) and 8 a.m. to 12 p.m. in the MMT (October, 2001). Average temperatures of 24 and $21{ }^{\circ} \mathrm{C}$ and relative humidities of 76 and $68 \%$ were recorded during the experiments in the JQT and MMT, respectively. The mean and range of $2 \mathrm{~h}$-concentrations of $\mathrm{CO}$, in ppm, and $\mathrm{NO}_{\mathrm{x}}$, in ppb, were 7.5 (7.5 - 7.6) and 423 (408 - 438), respectively, in JQT and $11.9(11.1-12.7)$ and 1100 (1020 - 1181), respectively, in MMT.

\section{Sampling procedures and analytical methods}

Carbonyls compounds were collected during $2 \mathrm{~h}$ at an air flow rate of $2.0 \mathrm{~L} \mathrm{~min}^{-1}$ on a silica gel cartridge (SepPak, Waters) previously cleaned with methanol and acetonitrile and coated with 2,4 dinitrophenylhydrazine (DNPH). An ozone trap, consisting of a KI cartridge (Waters) was connected to the upstream end of the cartridge to avoid ozone-sampling artifact. Gaseous aldehydes retained in the DNPH-silica cartridges were eluted with $5 \mathrm{~mL}$ of acetonitrile, and the extracts were stored in amber glass vials in a freezer until analysis by HPLC, on a Shimadzu model LC-9A, with UV detection at $360 \mathrm{~nm} .{ }^{16}$ For every two samples, one blank was analyzed. The detection limits of formaldehyde and acetaldehyde were respectively 0.171 and $0.129 \mathrm{ng}$. The blank of the acetone measurements was at maximum $15 \%$.

The concentration of carbonyls in air samples was calculated using the external calibration data for carbonylDNPH standards (Radian). Formaldehyde, acetaldehyde, acetone, acrolein, propionaldehyde, crotonaldehyde, 2-butanone, metacrolein, n-butyraldehyde, benzaldehyde, valeraldehyde, m-tolualdehyde and hexaldehyde were carbonyls compounds present in the standard mixture.

Gaseous carboxylic acids were collected during $2 \mathrm{~h}$ using a gas diffusion denuder, $6 \mathrm{~mm}$ i.d. $\mathrm{x} 50 \mathrm{~cm}$, coated with a solution of $5 \% \mathrm{~m} / \mathrm{v} \mathrm{Na} \mathrm{CO}_{3}$ at an air flow rate of 2.0 $\mathrm{L} \mathrm{min}^{-1}$. Gaseous carboxylic acids retained in the denuders were extracted with $20 \mathrm{~mL}$ of deionized water. The aqueous extracts were filtered in a Millipore HAWP $0.45 \mu \mathrm{m}$ membrane and stored in polyethylene flasks in a freezer until analysis. For every two samples collected, one blank was analyzed. Formic acid and acetic acid analysis was done using a Dionex model 4000i ion chromatographic system. ${ }^{17}$ Quantification was obtained through external standard comparison. The detection limits of anion standards were $0.100 \mathrm{ng}$ for acetate and $0.204 \mathrm{ng}$ for formate.

Half-one liter-air samples were collected during $5 \mathrm{~min}$ using a syringe and volatile organic compounds were retained on solid adsorbents (100:50, Tenax TA, 60/80 mesh, and Carbotrap, 20/40 mesh, from Supelco) packed into the stainless steel tubes (90 mm length; $6 \mathrm{~mm}$ outer diameter) and fixed with silanized glass wool. The adsorption tubes were conditioned for $24 \mathrm{~h}$ at $300{ }^{\circ} \mathrm{C}$ and by flushing them continuously with nitrogen at $30 \mathrm{~mL} \mathrm{~min}{ }^{-1}$. After sample collection, the adsorption tubes were placed inside an automated thermal desorption device (Tekmar, Aerotrap 6000). The VOCs were then thermally desorbed by flushing with helium the tubes heated at $225^{\circ} \mathrm{C}$ for $10 \mathrm{~min}$. The desorbed VOCs were cryogenically trapped at $-165^{\circ} \mathrm{C}$ in a 
trap packed with glass beads. Subsequently, the trap was heated to $240^{\circ} \mathrm{C}$ for $4 \mathrm{~min}$ and the sample cryofocused before injected into a chromatographic column (DB-1MS, $30 \mathrm{~m}$ length, $0.25 \mathrm{~mm}$ i.d.). A gas chromatograph (Shimadzu, model QP-5050A) equipped with a quadrupole mass spectrometer was used to analyze the gas samples. The temperature program of the gas chromatograph was: $-50^{\circ} \mathrm{C}$ (2 min) - @ $4^{\circ} \mathrm{C} \min ^{-1} 200^{\circ} \mathrm{C}$. The standard VOC mixture containing 10 ppbv benzene, m-and p-xylene (xyl), 1,3,5trimethylbenzene (TMB) and $n$-alkanes $\left(\mathrm{C}_{4}-\mathrm{C}_{12}\right)$ was used for comparing retention time of the peaks and for quantification as external standard. The limits of detection of the $n$-alkanes and single-ring aromatic compounds studied and the ions $(\mathrm{m} / \mathrm{z})$ monitored in the GC/MS analysis are presented in Table 2.

Table 2. Limits of detection of $n$-alkanes and aromatic compounds and the ions $(\mathrm{m} / \mathrm{z})$ monitored by GC/MS

\begin{tabular}{lcc}
\hline Compound & LD $(\mathrm{ng})$ & Fragment $(\mathrm{m} / \mathrm{z})$ \\
\hline$n$-butane & 0.024 & 43 \\
$n$-pentane & 0.016 & 43 \\
$n$-hexane & 0.038 & 57 \\
$n$-heptane & 0.024 & 43 \\
$n$-octane & 0.039 & 43 \\
$n$-nonane & 0.043 & 43 \\
$n$-decane & 0.071 & 57 \\
$n$-undecane & 0.040 & 57 \\
$n$-dodecane & 0.243 & 57 \\
benzene & 0.025 & 78 \\
m-, p-xylene & 0.059 & 91 \\
$1,3,5$-trimethylbenzene & 0.082 & 105 \\
\hline
\end{tabular}

\section{Results and Discussion}

\section{Measurements of oxygenated hydrocarbons}

Gaseous aldehydes and carboxylic acids are important constituents of the troposphere, for they contribute to a large fraction of the non-methane hydrocarbon mixture. These compounds may be emitted directly into the atmosphere by mobile and stationary sources and may also be produced in situ by the photo-oxidation of gas-phase hydrocarbons. Among the atmospheric aldehydes and organic acids, the lower molecular weight compounds $\left(\mathrm{C}_{1}\right.$ and $\mathrm{C}_{2}$ ) are the most abundant in urban air. There is a considerable variability in the aldehyde and carboxylic acid distribution when they are measured at different urban areas. ${ }^{11,17}$ In most of the measurements carried out in urban areas, formaldehyde levels are generally higher than acetaldehyde levels. However, formaldehyde/ acetaldehyde ratios from Brazil are normally low due to the substantial use of ethanol-containing fuels. ${ }^{11-13}$ Direct exhaust emissions of ethanol-fueled engine in Brazilian vehicles have been investigated, and higher mixing ratios of acetaldehyde than formaldehyde have been found. ${ }^{18}$

Measurements of formaldehyde and acetaldehyde have been carried out in several Brazilian tunnels located in different urban centers (Table 3 ), but a comparison between those carbonyl levels is difficult because of the great differences in the number and distribution of vehicles, fuel composition, percentage and type of catalyst-equipped vehicles, etc. However, measurements of acetic acid and formic acid were done only in one tunnel located in São Paulo City. ${ }^{17}$

In the present study, mixing ratios of carbonyl compounds and carboxylic acids were measured in two tunnels in São Paulo City, at different sampling times. Maximum and minimum mixing ratios of these oxygenated hydrocarbons in tunnel and ambient air are presented in Table 4. Results of ambient air measurements are from our previous work carried out at two urban sites located near JQT and MMT. ${ }^{3}$ In Figure 2 is illustrated the carbonyl compound and carboxylic acid relative

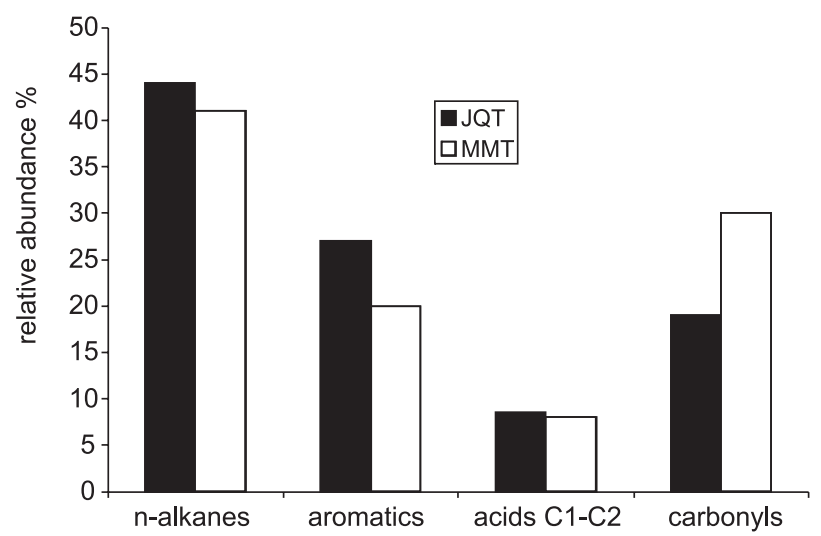

Figure 2. Relative abundance of volatile organic compounds found in the tunnels studied.

Table 3. Measurements of formaldehyde and acetaldehyde and their ratios in urban tunnels of Brazil

\begin{tabular}{lccr}
\hline Sampling site & HCHO (ppbv) & $\mathrm{CH}_{3} \mathrm{CHO}(\mathrm{ppbv})$ & $\mathrm{HCHO} / \mathrm{CH} \mathrm{CHO}_{3}$ \\
\hline Rio de Janeiro, RJ, 1987 & 70 & 241 & - \\
Salvador, BA, 1994 & $73.7-88.0$ & $54.8-93.0$ & - \\
São Paulo, SP, 1993 & $43-50$ & $40-60$ & 11 \\
São Paulo, SP, 1997 & $28-34$ & $31-37$ & 0.85 \\
São Paulo, SP, 2001 (JQT) & $23.7-30.6$ & $6.1-34.5$ & 0.89 \\
São Paulo, SP, 2001 (MMT) & $28.1-39.2$ & $24.8-32.2$ & 13 \\
\end{tabular}

* Results of this study. 
Table 4. Ranges of the oxygenated hydrocarbons mixing ratios in both tunnels and urban sites located near tunnels

\begin{tabular}{lcccc}
\hline Compound & \multicolumn{4}{c}{ Mixing ratio (ppbv) } \\
\cline { 2 - 4 } & \multicolumn{1}{c}{ JQT } & Ambient air ${ }^{\text {a }}$ & MMT & Ambient air ${ }^{\text {b }}$ \\
\hline Formaldehyde & $23.7-30.6$ & $3.3-45.6$ & $28.1-39.2$ & $1.0-46.3$ \\
Acetaldehyde & $33.7-34.5$ & $1.2-56.6$ & $24.8-32.2$ & $4.2-50.9$ \\
Formic acid & $2.4-4.3$ & $3.1-18.4$ & $5.2-7.5$ & $0.6-19.0$ \\
Acetic acid & $12.8-20.9$ & $0.5-6.4$ & $8.5-16.0$ & $1.9-10.6$ \\
\hline
\end{tabular}

${ }^{\text {a }}$ samples collected nearby JQT; ${ }^{3}$ b samples collected nearby MMT. ${ }^{3}$

abundance in both tunnels. Carbonyl compound emissions are higher in MMT (30\%) than in JQT (19\%), while carboxylic acids emissions are similar in both tunnels $(8.1 \%$ in MMT and $8.6 \%$ in JQT). According to William et al., diesel and methanol fueled engines produce significantly higher levels of aldehydes than gasoline engines. ${ }^{19}$

Direct emissions from vehicles may be defined as the principal source at an urban site if the formic/acetic and formaldehyde/acetaldehyde ratios found in the tunnel are similar to those observed in the urban site. Comparing our tunnel measurements with results of our previous work carried out at two urban sites located near JQT and $\mathrm{MMT}^{3}$, it is noted that formaldehyde/acetaldehyde ratios of tunnel samples (average, 0.8 for JQT and 1.0 for MMT) were slightly lower than those of urban samples collected nearby the tunnels (average, 1.4 for both sites). On the other hand, formic/acetic ratios of tunnel samples (average, 0.5 for MMT and 0.2 for JQT) were very lower than those of urban samples collected nearby the tunnel (average, 2.7 for urban site near JQT and 4.3 for urban site near MMT).

In several studies on measurements of gaseous carboxylic acids and aldehydes, the formic acid to acetic acid ratio and the formaldehyde to acetaldehyde ratio have been used to suggest their sources. The resulting ratio may be taken as an indicator of direct emission (low ratio, $<1$ ) and in situ formation by photochemical processes (high ratio, > 1). ${ }^{14,20-22}$

Our formaldehyde/acetaldehyde ratios from tunnel circulating vehicles fueled mainly with gasohol (JQT) were lower than 1 and ratios from tunnel circulating vehicles fueled with diesel and gasohol (MMT) were approximately equal to 1. In a previous study, available data on formaldehyde and acetaldehyde measured in JQT have also presented ratios $<1$ (ratio $=0.85)($ CETESB, 2000a), as well as aldehydes exhaust emissions data from gasohol engine of Brazilian vehicles (ratio $=0.57) .{ }^{17}$ Our tunnel formaldehyde/acetaldehyde ratios obtained at distinct collection periods were 0.88 (morning), 0.78 (midday) and 0.70 (afternoon) for JQT samples, and 1.1 (morning) and 1.0 (midday) for MMT samples. Since characteristic ratios for each tunnel were observed $(0.70$ 0.88 , JQT and $1.0-1.1$, MMT), these ratios seem to be dependent on the type of engine and fuel utilized.

Our tunnel measurements have shown higher acetic acid levels than formic acid levels. A ratio of 1:4, identical value of that observed in our 1996 experiments carried out in the JQT, was found for JQT samples and a ratio of 1:2 for MMT samples. In a previous study, acetic acid was the most abundant carboxylic acid in gasoline motor exhaust emissions and formic acid was the most abundant carboxylic acid in diesel motor exhaust emissions. ${ }^{23}$ Our tunnel formic/acetic ratios obtained at different collection periods were 0.28 in the morning, 0.11 in the midday and 0.28 in the afternoon for JQT samples; and 0.61 in the morning, 0.47 in the midday for MMT samples. Like carbonyl ratios, characteristics formic/acetic ratios were found for each tunnel $(0.11-0.28$, JQT and $0.47-0.61$, MMT) and they appear to be also dependent on the type of engine and fuel utilized.

According to Kawamura et al., if acids and aldehydes are significantly emitted from vehicles, it may be supposed that aldehydes are preferentially lost or, alternatively, that acids are preferentially formed by photochemical processes, resulting in an accumulation of acids in the air and leading to average ratios of acids/aldehydes higher than those of vehicle exhaust. ${ }^{23}$ In the present study, average ratios of measured organic acid and aldehyde concentrations were equal to 0.29 for the MMT and 0.34 for the JQT. In our atmospheric samples collected in a previous experiment, the acid to aldehyde average ratio was 0.39 for the urban site near MMT and 0.60 for the urban site near JQT. ${ }^{3}$ By examining our results, the ratios of atmospheric samples were also higher than those of tunnel samples, mostly at the urban site near JQT.

A profile of carbonyl compounds of higher molecular weight than $\mathrm{C}_{2}$ in both tunnels, given in normalized mixing ratio, is presented in Figure 3. Acetone, propionaldehyde, crotonaldehyde and benzaldehyde were the most predominant carbonyl compounds in the JQT, whereas acetone, propionaldehyde and acrolein were the most predominant carbonyl compounds in the MMT. It is interesting to mention here that high background levels of acetone are usually found in the laboratory air and a contamination in the samples often occur. Therefore, analytical results of acetone in air measurements must be taken into consideration carefully. The most abundant carbonyl compounds $\left(>\mathrm{C}_{2}\right)$ in each tunnel may be used to 


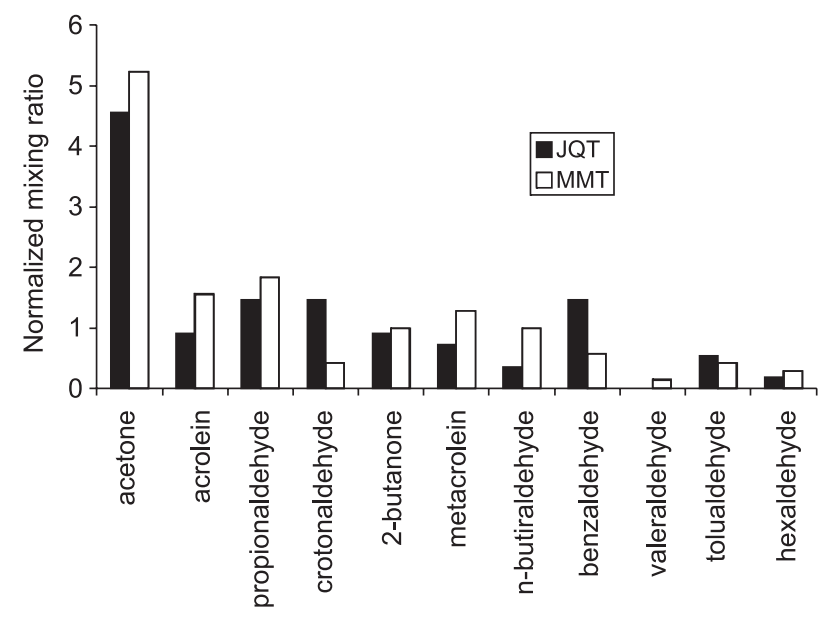

Figure 3. Profile of carbonyl compounds with longer chain than $C_{2}$ in both tunnels studied.

indicate possible tracers. In our tunnel experiment, benzaldehyde was one of the most predominant carbonyl compounds $\left(>\mathrm{C}_{2}\right)$ in the JQT and it may be taken as a tracer of light-duty gasohol vehicular emissions. Mixing ratios of benzaldehyde as high as formaldehyde or acetaldehyde have been found in gasoline vehicular motor exhausts. ${ }^{23}$ Although crotonaldehyde appears to be also predominant in the JQT, it may not be suggested as a tracer of light-duty gasohol vehicular emissions due to its reactivity. For MMT, tracers of vehicular emissions were not proposed as a mixture of both gasohol and diesel vehicular emissions were predominantly presented inside this tunnel.

\section{Measurements of aliphatic and aromatic hydrocarbons}

Characterization of aliphatic and aromatic hydrocarbons of vehicular emissions in tunnels air has been presented in recent studies. ${ }^{6,7,15,24}$ In our tunnel experiments, $\mathrm{C}_{4}-\mathrm{C}_{12} n$-alkanes, and benzene, $\mathrm{m}$-, $\mathrm{p}$-xylenes and 1,3,5-trimethylbenzene were determined. Maximum and minimum mixing ratios of these compounds for both tunnels studied ( $\mathrm{n}=7$, for JQT and $\mathrm{n}=2$, for MMT) are presented in Table 5. Toluene was not determined in this study as its standard was not available in our laboratory. Mixing ratios of these hydrocarbons, in general, were higher in the gasohol emission tunnel (JQT), specially, benzene and $\mathrm{m}, \mathrm{p}$-xylene that presented higher levels than those in the diesel-and-gasohol emissions tunnel (MMT).

As expected, much higher levels of $n$-alkanes and single-ring aromatic compounds were found in tunnel air compared to those observed in ambient air (see Table 5). By examining $n$-alkanes from tunnels, the most abundant species was $n$-pentane ranged from 21.1 to $40.0 \mathrm{ppbv}$ for JQT and 26.2 to $26.9 \mathrm{ppbv}$ for MMT. Among the tunnel single-ring aromatic compounds, the most predominant species was m,p-xylenes ranged from 21.6 to $43.1 \mathrm{ppbv}$ for JQT samples and 21.4 to 24.8 ppbv for MMT samples.

In a recent experiment performed in a tunnel of São Paulo, lower levels of $n$-alkanes and single-ring aromatic compounds were found. ${ }^{15}$ These data, however, should be compared carefully, as VOCs measurements were carried out by different experimental procedures. Moreover, variables, such as vehicular fleet features may affect VOC chemical composition.

\section{Conclusions}

Among organic compound classes studied, $n$-alkanes were the most abundant compound class (similar levels in both tunnels) followed by carbonyl compounds (higher levels in MMT), and aromatics compounds (higher levels in JQT). On the other hand, organic acids, the minor species, were found at similar levels in both tunnels. By using our tunnels measurements, formaldehyde/acetaldehyde ratios from vehicular emissions of the fuels used in São Paulo

Table 5. Maximum and minimum values of $n$-alkanes and single-ring aromatic compounds mixing ratios found in both tunnels and in an urban site

\begin{tabular}{lccc}
\hline \multirow{2}{*}{ Compound } & \multicolumn{3}{c}{ Mixing ratio (ppbv) } \\
\cline { 2 - 4 } & \multicolumn{1}{c}{ JQT } & MMT & Ambient air a \\
\hline$n$-butane & $9.7-27.3$ & $12.4-25.7$ & $0.15-1.57$ \\
$n$-pentane & $21.1-40.0$ & $26.2-26.9$ & $0.13-0.94$ \\
$n$-hexane & $5.2-22.0$ & $10.1-19.2$ & $0.16-2.18$ \\
$n$-heptane & $4.3-23.3$ & 17.5 & $0.21-0.91$ \\
$n$-octane & $4.2-8.6$ & $2.9-6.0$ & $0.04-0.45$ \\
$n$-nonane & $3.2-6.4$ & $2.9-3.7$ & $0.04-0.53$ \\
$n$-decane & $2.9-5.0$ & $2.7-3.3$ & $0.43-0.90$ \\
$n$-undecane & $2.4-5.2$ & $2.5-3.3$ & $0.74-1.10$ \\
$n$-dodecane & $4.5-7.7$ & $4.4-6.2$ & $0.97-1.71$ \\
benzene & $13.9-24.8$ & $13.7-16.6$ & $0.17-2.13$ \\
m-, p-xylenes & $21.6-36.4$ & $21.4-24.8$ & $2.22-8.38$ \\
1,3,5-trimethylbenzene & $8.7-16.4$ & $8.2-10.2$ & $0.87-1.77$
\end{tabular}

${ }^{a}$ samples collected nearby JQT in our experiment of 2001. 
were determined. Thus, ratios $<1$ for vehicles mainly with gasohol-fueled engines (JQT), and ratios approximately equal to 1 for vehicles mainly with diesel-and-gasoholfueled engines (MMT) were observed. According to our results, benzaldehyde was suggested as a possible tracer of light-duty gasohol vehicular emissions.

Comparing carboxylic acids measurements, much higher acetic acid levels than formic acid levels were found in both tunnels, (ratios < 1). Formaldehyde/acetaldehyde and formic/acetic acid ratios for each tunnel were similar at collection periods studied, which suggests that such ratios are also dependent on the type of the engine and fuel utilized.

Results of this survey indicate that VOCs are present at significant levels in both urban road tunnels studied. Certainly further investigations are necessary to establish with more accuracy the occurrence of these compounds, in special, at rush hours when traffic jams are frequent.

\section{Acknowledgments}

This work has been supported in part by grants from FAPESP, Fundação de Amparo à Pesquisa do Estado de São Paulo (Project 96/0143-4). C.S.P. thanks CNPq, Conselho Nacional de Desenvolvimento Científico e Tecnológico, for the graduate fellowship.

\section{References}

1. Hsieh, C; Chang, K.; Kao, Y.; Chemosphere 1999, 39, 1433.

2. Barrefors, G.; Sci. Total Environ. 1996, 189/190, 431.

3. Montero, L.; Vasconcellos, P. C.; Souza, S. R.; Pires, M. A. F.; Sanchez-Ccoyollo, O. R.; Andrade, M. F.; Carvalho, L. R. F.; Environ. Sci. Technol. 2001, 35, 3071.

4. Pierson, W.R.; Gertler, A.W.; Robinson, N.F.; Sagebiel, J.C.; Zielinska, B.; Bishop, G.; Stedman, D.; Zweidinger, R.B.; Ray, W.D.; Atmos. Environ.1996, 30, 2233.

5. Chan, L.Y.; Zeng, L.; Qin, Y.; Lee, S.C.; Environ. Internat. 1996, 22, 405.
6. Touaty, M.; Bonsang, B.; Atmos. Environ. 2000, 34, 985.

7. Hsu, Y.; Tsai, J.; Chen, H.; Lin, W.; Chemosphere 2001, 42, 227.

8. Azevedo, D.A.; Santos, C.Y.M.; Aquino Neto, F.R.; Atmos. Environ. 2002, 36, 2382.

9. Pereira, P.A.P.; Andrade, J.; Miguel, A.; J. Environ. Monit. 2002, 4, 558.

10. Vasconcellos, P. C.; Zacarias, D.; Pires, M. A.; Pool, C.; Carvalho, L. R. F.; Atmos. Environ. 2003, 37, 3009.

11. Grosjean, D.; Miguel, A.H.; Tavares, T.; Atmos. Environ. 1990, 24B, 101.

12. Andrade, J.B.; Pinheiro, H.L.C.; Andrade, M.; J. Braz. Chem. Soc. 1995, 6, 287.

13. CETESB Relatório de aldeídos na atmosfera de São Paulo 1996/1997, 2000, Série Relatórios, São Paulo.

14. Souza, S.R.; Carvalho, L.R.F.; Quím. Nova 1997, 20, 245.

15. Colón, M.; Pleil, J. M. D.; Hartlage, T. A.; Guardan, M. L.; Martins, M. L. H.; Atmos. Environ. 2001, 35, 4017.

16. Pires, M.; Carvalho, L.R.F.; Anal. Chim. Acta 1998, 367, 223.

17. Souza, S.R.; Vasconcellos, P.C.; Carvalho, L.R.F.; Atmos. Environ. 1999, 33, 2563.

18. CETESB private communication, 2000, São Paulo.

19. Hwa, M.Y.; Hsieh, C.C.; Wu, T.C.; Chang, L.F.; Atmos. Environ. 2002, 36, 1993.

20. Khwaja, H. A.; Atmos. Environ. 1995, 29,127.

21. Kumar, N.; Kulshresta, U. C.; Khare, P.; Saxena, A.; Kumari, K. M.; Srivastava, S.S.; Atmos. Environ. 1996, 30, 3545.

22. Granby, K.; Egelov, A. H.; Nielsen, T.; Lohse, C.; J. Atmos. Chem. 1997, 28, 195.

23. Kawamura, K.; Steinberg, S.; Kaplan, I.R.; Atmos. Environ. 2002, 34, 4175.

24. Williams, I.D.; Revitt, D.; Hamilton, R. S.; Sci. Total Environ. 1996, 189/190, 475.

Received: November 25, 2004

Published on the web: September 15, 2005

FAPESP helped in meeting the publication costs of this article. 